\title{
QTLs for Resistance to Major Rice Diseases Exacerbated by Global Warming: Brown Spot, Bacterial Seedling Rot, and Bacterial Grain Rot
}

\author{
Ritsuko Mizobuchi ${ }^{1}$, Shuichi Fukuoka', Seiya Tsushima ${ }^{2}$, Masahiro Yano ${ }^{3}$ and Hiroyuki Sato ${ }^{4 *}$
}

\begin{abstract}
In rice (Oryza sativa L.), damage from diseases such as brown spot, caused by Bipolaris oryzae, and bacterial seedling rot and bacterial grain rot, caused by Burkholderia glumae, has increased under global warming because the optimal temperature ranges for growth of these pathogens are relatively high (around $30^{\circ} \mathrm{C}$ ). Therefore, the need for cultivars carrying genes for resistance to these diseases is increasing to ensure sustainable rice production. In contrast to the situation for other important rice diseases such as blast and bacterial blight, no genes for complete resistance to brown spot, bacterial seedling rot or bacterial grain rot have yet been discovered. Thus, rice breeders have to use partial resistance, which is largely influenced by environmental conditions. Recent progress in molecular genetics and improvement of evaluation methods for disease resistance have facilitated detection of quantitative trait loci (QTLs) associated with resistance. In this review, we summarize the results of worldwide screening for cultivars with resistance to brown spot, bacterial seedling rot and bacterial grain rot and we discuss the identification of QTLs conferring resistance to these diseases in order to provide useful information for rice breeding programs.
\end{abstract}

Keywords: Oryza sativa L, Disease resistance, Brown spot, Seedling rot, Grain rot, Panicle blight, Bipolaris oryzae, Burkholderia glumae

\section{Introduction}

Climate changes have widespread impacts on human life. The Intergovernmental Panel on Climate Change (IPCC) published the Fifth Assessment Report (AR5) in 2014 which provided a clear and up-to-date view of the current state of scientific knowledge relevant to climate change. According to this report, warming of the climate system is unequivocal, and many of the observed changes are unprecedented over decades to millennia (IPCC 2014). Specifically, the globally averaged combined land and ocean surface temperature data as calculated using a linear model show warming of $0.85{ }^{\circ} \mathrm{C}$ over the period 1880 to 2012 (IPCC 2014).

\footnotetext{
* Correspondence: bsato@affrc.go.jp

${ }^{4}$ National Agriculture and Food Research Organization, Kyushu Okinawa Agricultural Research Center (NARO/KARC), 496 Izumi, Chikugo, Fukuoka 833-0041, Japan

Full list of author information is available at the end of the article
}

Among its many effects, global warming influences the distribution, incidence and severity of plant disease worldwide (Juroszek and von Tiedemann 2015). In rice (Oryza sativa L.), many pests and the pathogens they transmit are influenced by global warming. For example, a geographical shift in the prevalence of rice stripe virus disease, transmitted by the small brown planthopper, is predicted to result from global warming in Japan (Yamamura and Yokozawa 2002). In addition, several pathogens are expected to be directly influenced by global warming. Among these are pathogens that cause agriculturally important diseases such as sheath blight, caused by Rhizoctonia solani, brown spot (BS), caused by Bipolaris oryzae, and bacterial seedling rot (BSR) and bacterial grain rot (BGR), both caused by Burkholderia glumae, because the optimal temperature ranges for growth of these pathogens are relatively high (around $30{ }^{\circ} \mathrm{C}$ ). Sheath blight is considered as one of the three major diseases of rice (along with 
blast and bacterial blight) (Zou et al. 2000; Hu et al. 2008; Liu et al. 2010), and many studies have been done to enhance resistance to sheath blight. A review covering QTLs for resistance to sheath blight has been published recently (Zeng et al. 2015), so this topic is not covered here.

Compared with the extensive research on sheath blight, less research has been done to enhance resistance to BS, BSR and BGR. However, reports of damage caused by these diseases are increasing under global warming conditions because, as noted above, their optimal growth temperatures are relatively high (Ham et al. 2011b; Savary et al. 2011). The optimal temperatures for conidial germination and hyphal germination of Bipolaris oryzae are 25-30 ${ }^{\circ} \mathrm{C}$ and $27-30{ }^{\circ} \mathrm{C}$, respectively (Barnwal et al. 2013), and the optimal temperature range for the growth of Burkholderia glumae is $30-35{ }^{\circ} \mathrm{C}$ (Kurita et al. 1964; Tsushima et al. 1986).

According to a recent review (Barnwal et al. 2013), BS is currently regarded as a serious rice disease worldwide. BS was identified in 1892 in Japan (Ohata 1989) and can often considerably decrease grain yield and quality. For example, this disease was the main cause of the Bengal famine of 1943 (Padmanabhan 1973). More recently, BS has been also reported in Brazil (Schwanck et al. 2015) and in East and Southeast Asian countries (Savary et al. 2000b) and India (Reddy et al. 2010), and the reported yield losses vary from 4 to $52 \%$ (Savary et al. 2000a; Barnwal et al. 2013). The damage caused by BS generally becomes noticeable when rice is grown in nutritionally deficient or otherwise unfavorable soil conditions (Katara et al. 2010). Yield losses due to BS have been estimated to range between $16 \%$ and $43 \%$ on Histosols, which are Sideficient (Datnoff et al. 1991). In 2013, the epidemic area of BS in Japan covered 187,714 ha, making it the fourth most prevalent rice disease of that year (after sheath blight, leaf blast and neck blast) (JPPA 2014).

BGR and BSR are also increasingly important diseases in global rice production (Ham et al. 2011b). The term 'bacterial panicle blight' is also used to refer to BGR, mainly in the United States and Latin American countries (Ham et al. 2011b). The causal organism of these diseases, Burkholderia glumae, was identified in 1955 in Japan (Goto and Ohata 1956; Kurita and Tabei 1967; Uematsu et al. 1976; Goto et al. 1987) and has also been reported in the United States (Nandakumar et al. 2009), East and South Asia (Chien and Chang 1987; Trung et al. 1993; Cottyn et al. 1996a; Cottyn et al. 1996b; Jeong et al. 2003; Luo et al. 2007), Latin America (Zeigler and Alvarez 1989; Nandakumar et al. 2007b) and South Africa (Zhou 2014). In 2013, the epidemic area of BGR in Japan covered 69,799 ha, making it the sixth most prevalent disease (following leaf stripe, the fifth most prevalent disease) of that year (JPPA 2014). In the United States, Burkholderia glumae has been identified as the major causal agent of
BGR (Shahjahan et al. 2000; Nandakumar et al. 2005; Nandakumar et al. 2009). In the southern United States, yield losses caused by outbreaks of BGR in rice fields in Arkansas were up to $50 \%$ in 2010 and 2011; significant losses caused by this disease were also experienced in other recent years (Shahjahan et al. 2000; Nandakumar et al. 2009; Ham et al. 2011a; Ham et al. 2011b; Zhou et al. 2011; Wamishe et al. 2014).

As illustrated above, it is necessary to breed rice cultivars with resistance to BS, BSR and BGR. To date, several research groups have successfully identified cultivars with some level of resistance to these diseases. However, despite extensive efforts, no single genes or QTLs for complete resistance to BS, BSR or BGR have been discovered. Recent progress in molecular genetics and improvement of evaluation methods for disease resistance have allowed us to identify several quantitative trait loci (QTLs) to enhance resistance to these pathogens. In this review, we focus on host plant resistance to BS, BSR and BGR. We summarize the research on QTLs related to resistance to these diseases and discuss the potential utility of these QTLs for rice breeding.

\section{Review}

\section{Screening cultivars for brown spot (BS) resistance}

Several studies have been conducted to screen cultivars for BS resistance (Table 1 ). Rice plants are highly susceptible to BS at the seedling stage and between the booting and flowering stages (Chakrabarti 2001). In 1930, 'Kutto-urupe', which was described as a Korean native cultivar, was found to be more susceptible than other cultivars by field observation without artificial inoculation (Nagai and Hara 1930); this was the first report that showed varietal differences in BS resistance levels. Later, 'Mubo-Aikoku' was found to be resistant to BS by seedling inoculation tests in the United States (Adair 1941). Yoshii and Matsumoto applied spray inoculation to plants of different stages (seedling, tillering, booting and flowering) and demonstrated that two cultivars ('Tetep' and 'Ginnen') were resistant and another six cultivars, including 'Tadukan', were moderately resistant (Yoshii and Matsumoto 1951). In Egypt, 'Pi1' and 'YNA282' were categorized as resistant (Balal et al. 1979).

As summarized by Barnwal et al. (Barnwal et al. 2013), damage by BS has long been associated with soil fertility (Ou 1985; Ohata 1989). Moreover, the effects of soil nutrients depend on the redox potential of the soil in fields containing sandy loam and peat soil (Ou 1985; Ohata 1989; Barnwal et al. 2013). In Japan, the damage by BS was found to be quite severe on low-K soil (Ono 1953), sandy loam and peat soil (Ohata 1989). Therefore, screening was conducted in fields having different soil conditions (K-deficient field, sandy loam and peat soil) over 11 years, and two cultivars and 20 breeding lines 
Table 1 Previous reports of screening cultivars and breeding lines for brown spot (BS) resistance

\begin{tabular}{|c|c|c|c|c|c|}
\hline Year & Country $^{a}$ & $\begin{array}{l}\text { Resistant cultivars and } \\
\text { breeding lines }\end{array}$ & $\begin{array}{l}\text { Number of screened } \\
\text { cultivars or lines }\end{array}$ & Evaluation method & Reference(s) \\
\hline 1930 & Japan & $\begin{array}{l}\text { (Kutto-urupe identified } \\
\text { as a susceptible cultivar) }\end{array}$ & - & $\begin{array}{l}\text { Field observation without } \\
\text { artificial inoculation }\end{array}$ & Nagai and Hara (1930) \\
\hline 1941 & USA & Mubo-Aikoku & 16 & Inoculation of seedlings & Adair (1941) \\
\hline \multirow[t]{2}{*}{1951} & Japan & Resistant: Tetep, Ginnen & 20 & $\begin{array}{l}\text { Inoculation of different } \\
\text { growth stages (seedling, } \\
\text { tillering, booting and } \\
\text { flowering) }\end{array}$ & Yoshii and Matsumoto (1951) \\
\hline & & $\begin{array}{l}\text { Moderately resistant: Tadukan, } \\
\text { Bomba, Jamaica, Louisiana } \\
\text { non-beard, Choukakou, } \\
\text { Shimoushaku }\end{array}$ & & & \\
\hline 1962 & Japan & $\begin{array}{l}\text { Kairyo-Aikoku, Ginbozu and } 20 \\
\text { breeding lines }\end{array}$ & 45 & $\begin{array}{l}\text { Field observation between } \\
\text { different soils (K-deficient field, } \\
\text { sandy loam and peat soil) over } \\
11 \text { years }\end{array}$ & Yasumasa et al. (1962) \\
\hline 1974 & Japan & $\begin{array}{l}\text { Tadukan, Tetep, Jamaica, Pi } \\
\text { No.1, Kararato, Choukakou, } \\
\text { Usen, Ginnen }\end{array}$ & 80 & Inoculation of seedlings & $\begin{array}{l}\text { Ohata and Kubo (1974), } \\
\text { Ohata (1989) }\end{array}$ \\
\hline 1979 & Egypt & $\mathrm{Pi1}$, YNA282 & 5 & $\begin{array}{l}\text { Inoculation at four stages } \\
\text { (seedling, maximum tillering, } \\
\text { maximum heading and milk- } \\
\text { ripe stage) }\end{array}$ & Balal et al. (1979) \\
\hline 1985 & India & $\mathrm{CH} 45$ & - & $\begin{array}{l}\text { Field observation without } \\
\text { artificial inoculation }\end{array}$ & Misra (1985) \\
\hline 1986 & USA & $\begin{array}{l}\text { Dawn, Taichung Native-1, } \\
\text { Tetep }\end{array}$ & 11 & $\begin{array}{l}\text { Inoculation of 45-day-old- } \\
\text { plants }\end{array}$ & Eruotor (1986) \\
\hline 1994 & USA & Katy, Experimental Line $1^{\mathrm{b}}$ & 10 & $\begin{array}{l}\text { Field observation without } \\
\text { artificial inoculation } \\
\text { (Si-deficient soil, Histosol) }\end{array}$ & Deren et al. (1994) \\
\hline 1995 & India & $\begin{array}{l}\text { Jhllidhan (HRC 703), Kalamdani } \\
\text { (HRC 711), Tulsimanjari } \\
\text { (HRC 719), Bankuiya } \\
\text { (HRC 729), Marto (NIC 105696) }\end{array}$ & 183 & $\begin{array}{l}\text { Field observation without } \\
\text { artificial inoculation over } \\
4 \text { years }\end{array}$ & Shukla et al. (1995) \\
\hline 2004 & Bangladesh & Line $139^{c}$ & 33 & $\begin{array}{l}\text { Field observation without } \\
\text { artificial inoculation over } \\
2 \text { years }\end{array}$ & Hossain et al. (2004) \\
\hline \multirow[t]{2}{*}{2005} & India & $\begin{array}{l}\text { Resistant: Khazar, Teqing, } \\
\text { Tarommolaii, IR6, Chhomrong, } \\
\text { Govind, UPR191-66, ASD18, } \\
\text { R644, Yuanjing7, Xu-Xiangzan, } \\
\text { BG90-2, TKM9, Guang122 }\end{array}$ & 124 & $\begin{array}{l}\text { Inoculation of 70-day-old- } \\
\text { plants after transplanting }\end{array}$ & Satija et al. (2005) \\
\hline & & $\begin{array}{l}\text { Moderately resistant: RASI, } \\
\text { IR64, CR203, IR50, BG304, } \\
\text { Lemont, Phalguna, PR111 }\end{array}$ & & & \\
\hline 2006 & India & $\begin{array}{l}\text { CR 100117, CR 100140, CR } \\
\text { 100142, CR100142A (all are } \\
\text { Oryza nivara germplasm) }\end{array}$ & 150 & $\begin{array}{l}\text { Inoculation of 90-day-old } \\
\text { plants (all accessions were O. } \\
\text { nivara) }\end{array}$ & Goel et al. (2006) \\
\hline 2006 & India & $\begin{array}{l}\text { (PR116, PR114 and PR106 } \\
\text { detected as susceptible } \\
\text { cultivars) }\end{array}$ & 9 & $\begin{array}{l}\text { Field observation without } \\
\text { artificial inoculation over } \\
3 \text { years }\end{array}$ & Pannu et al. (2006) \\
\hline
\end{tabular}

${ }^{a}$ Country where experiment was conducted

${ }^{b}$ Experimental Line 1 is an advanced line from the breeding program in Arkansas

${ }^{\mathrm{C}} \mathrm{A}$ breeding line

were found to be resistant (Yasumasa et al. 1962). BS was also reported to be severe on low-Si soils (Datnoff et al. 1991; Datnoff et al. 1997), and the effect of Si on resistance to BS was ascertained recently by using a $\mathrm{Si}$ - transporter mutant (Dallagnol et al. 2014). By evaluating cultivars and breeding lines on Si-deficient soil, two were found to be resistant to BS (Deren et al. 1994). In a screen of 80 cultivars in 1974, eight cultivars including 
'Tadukan' were found to be resistant to many strains (Ohata and Kubo 1974; Ohata 1989). Among these cultivars, 'Tadukan', 'Tetep', 'Choukakou' and 'Ginnen' were categorized as resistant by two research groups independently (Yoshii and Matsumoto 1951; Ohata and Kubo 1974; Ohata 1989). 'Tetep' was also categorized as resistant by another research group of the United States (Eruotor 1986).

Until the 20th century, most reports of BS were from Japan, but more recent reports from Bangladesh and India suggest that the damage by BS in South Asia has become serious (Chakrabarti 2001). In Bangladesh, 'Line 139' was reported to be resistant by field evaluation (Hossain et al. 2004). In three independent studies in India, more than 183 cultivars in total were screened and 28 showed partial resistance to BS (Misra 1985; Shukla et al. 1995; Satija et al. 2005). By field observation without artificial inoculation during 3 years in different districts in Punjab state of North India, three cultivars were categorized as susceptible (Pannu et al. 2006). Goel et al. (2006) evaluated 150 accessions of Oryza nivara (wild rice), and found that four were resistant to BS.

\section{Analysis of QTLs for resistance to brown spot (BS)}

Several cultivars that have been categorized as resistant did not show complete resistance (immunity) to BS (Sreedharan and Menon 1974). Some varieties such as 'Tadukan' and 'Tetep' showed quantitative resistance to BS (Yoshii and Matsumoto 1951; Ohata and Kubo 1974; Eruotor 1986; Ohata 1989). The first QTL analysis for resistance to BS was conducted in 2008 (Sato et al. 2008a) (Table 2). In that study, a set of recombinant inbred lines (RILs) derived from a cross between 'Tadukan' (resistant) and 'Hinohikari' (susceptible) was used to identify QTLs conferring resistance to BS at the seedling stage in a greenhouse screen. Three QTLs ( $q B S 2, q B S 9$ and $q B S 11$ ) were detected on chromosomes 2,9 and 11 , respectively. Among them, $q B S 11$ had the highest logarithm of odds (LOD) score (LOD = 5.11 in CIM (composite interval mapping) and 2.82 in IM (interval mapping)) and could be considered a major QTL. The 'Tadukan' allele explained 11.9 to $15.3 \%$ of the phenotypic variation in the $\mathrm{F}_{5}$ population. The $q B S 9$ allele from 'Tadukan' could explain 9.7 to $12.9 \%$ of the phenotypic variation, while the $q B S 2$ allele from 'Hinohikari' could account for $11.1 \%$ of the total phenotypic variation.

To confirm the effects of these QTLs, advanced generations of the RILs and their parents were transplanted into a BS-infected paddy field and evaluated for resistance in 2012 and 2013. In that study, three QTLs for field resistance to BS ( $q B S f R 1, q B S f R 4$ and $q B S f R 11$ ) were detected (Sato et al. 2015). The 'Tadukan' alleles at $q B S f R 1$ and $q B S f R 11$ and the 'Hinohikari' allele at $q B S f R 4$ enhanced resistance to BS. The QTL with the largest effect, $q B S f R 11$, explained 17.9 and $19.2 \%$ of the phenotypic variation in 2012 and 2013, respectively, and was thought to coincide with $q B S 11$, which had been detected at the seedling stage (Sato et al. 2008a). Therefore, the resistance derived from $q B S f R 11$ ( $q B S 11$ ) was consistently detectable regardless of growth stages. To verify the resistance conferred by the 'Tadukan' alleles at $q B S f R 1$ and $q B S f R 11$, near-isogenic lines (NILs) containing each of these QTL alleles from 'Tadukan' in the background of susceptible variety 'Koshihikari' were bred and evaluated under field conditions. A NIL containing the 'Tadukan' allele at $q B S f R 11$ acquired significant BS field resistance, but that with the 'Tadukan' allele at qBSfR1 did not. Besides 'Tadukan', 'Kasalath' was also identified as a resistant cultivar (Sato et al. unpublished data). By using chromosome segment substitution lines (CSSLs) derived from a cross between 'Kasalath' and 'Koshihikari', Sato et al. (2008b) detected one QTL located on chromosome 9 near $q B S 9$.

Because soil fertility is known to affect BS levels, Katara et al. (2010) searched for QTLs associated with field resistance to BS in rice grown on two different soil types: Vertisol and Inceptisol. According to the report, Vertisol is easily recognized because of its clayey texture, dark color, and unique physical characteristics and is very productive if well managed, but presents challenges to low-input agriculture (Katara et al. 2010). Inceptisols are mineral soils that have significant subsoil or surface alteration. Using doubled haploid (DH) lines derived from a cross between 'CT 9993-5-10-1-M' (resistant) and 'IR 62266-42-6-2' (susceptible), a total of 11 QTLs were detected, four of which $(B S q 2.1 v \mathcal{E} i, B S q 2.2 v \mathcal{E} i$, $B S q 4.1 v \mathcal{E} i$ and $B S q 11.1 v \mathcal{E} i$ ) were detected in tests on both soil types (Katara et al. 2010). BSq4.1vE $i$ and $B S q 11.1 v \mathcal{E} i$, which are located on chromosomes 4 and 11 , respectively, explained the highest percentages of phenotypic variation. $B S q 4.1 v \mathcal{E} i$ explained $18.5 \%$ of the total phenotypic variation when rice was grown on Vertisol and $22.3 \%$ when grown on Inceptisol. $B S q 11.1 v \mathcal{E} i$ explained $13.1 \%$ of the total phenotypic variation when rice was grown on Vertisol and $12.9 \%$ when grown on Inceptisol. Comparing the QTLs detected by Sato et al. (2008a, b) with those of Katara et al. (2010), four chromosomal regions may be common to both studies: (1) $q B S 2$ and $B S q 2.2 v \mathcal{E} i$, (2) $q B S f R 4$ and $B S q 4.1 v \mathcal{E} i$, (3) qBS9, unnamed QTL reported in Sato et al. (2008b) and BSq9.1v, and (4) qBS11, qBSfR11, and BSq11.2v.

Two QTLs were identified from $\mathrm{F}_{2}$ lines derived from a cross between landrace 'Dinorado' (resistant) and 'IR36' (susceptible) and bs1 was located on chromosome 12 (Banu et al. 2008). On the basis of map information, bs1 seems to be different from BSq12.1v (Katara et al. 2010; 
Table 2 QTLs for brown spot (BS) resistance

\begin{tabular}{|c|c|c|c|c|c|}
\hline Chromosome & $\mathrm{QTL}^{\mathrm{a}}$ & $\begin{array}{l}\text { Source of } \\
\text { resistance allele }\end{array}$ & Materials used for QTL analysis ${ }^{b}$ & Phenotyping method & Reference \\
\hline 1 & $q B S f R 1$ & Tadukan & $\begin{array}{l}110 \text { RILs (Tadukan (R) } \\
\text { and Hinohikari (S)) }\end{array}$ & $\begin{array}{l}\text { Field evaluation at } 113 \text { days } \\
\text { after transplanting by promoting } \\
\text { disease with inoculated spreader }\end{array}$ & Sato et al. (2015) \\
\hline 2 & $B S q 2.1 v \& i$ & IR62266-42-6-2 & $\begin{array}{l}\text { 154 DH lines (CT9993-5-10-1 } \\
M(\mathrm{R}) \text { and IR62266-42-6-2 (S)) }\end{array}$ & $\begin{array}{l}\text { Field evaluation without artificial } \\
\text { inoculation } \\
\text { (Vertisol and Inceptisol soils) }\end{array}$ & Katara et al. (2010) \\
\hline 2 & $q B S 2$ & Hinohikari & $\begin{array}{l}110 \text { RILs (Tadukan (R) } \\
\text { and Hinohikari (S)) }\end{array}$ & $\begin{array}{l}\text { Inoculation of 18-day-old-plants } \\
\text { in greenhouse }\end{array}$ & Sato et al. (2008a) \\
\hline 2 & $B S q 2.2 v \& i$ & IR62266-42-6-2 & $\begin{array}{l}154 \text { DH lines (CT9993-5-10-1 } \\
M(R) \text { and IR62266-42-6-2 (S)) }\end{array}$ & $\begin{array}{l}\text { Field evaluation without artificial } \\
\text { inoculation (Vertisol and Inceptisol soils) }\end{array}$ & Katara et al. (2010) \\
\hline 4 & qBSfR4 & Hinohikari & $\begin{array}{l}110 \text { RILs (Tadukan (R) } \\
\text { and Hinohikari (S)) }\end{array}$ & $\begin{array}{l}\text { Field evaluation at } 113 \text { days after } \\
\text { transplanting by promoting disease } \\
\text { with inoculated spreader }\end{array}$ & Sato et al. (2015) \\
\hline 4 & $B S q 4.1 v \& i$ & СТ9993-5-10-1 M & $\begin{array}{l}154 \mathrm{DH} \text { lines (CT9993-5-10-1 } \\
\mathrm{M}(\mathrm{R}) \text { and IR62266-42-6-2 (S)) }\end{array}$ & $\begin{array}{l}\text { Field evaluation without artificial } \\
\text { inoculation (Vertisol and Inceptisol soils) }\end{array}$ & Katara et al. (2010) \\
\hline 6 & $B S q 6.1 \mathrm{~V}$ & СТ9993-5-10-1 M & $\begin{array}{l}154 \mathrm{DH} \text { lines (CT9993-5-10-1 } \\
\mathrm{M}(\mathrm{R}) \text { and IR62266-42-6-2 (S)) }\end{array}$ & $\begin{array}{l}\text { Field evaluation without artificial } \\
\text { inoculation (Vertisol soil) }\end{array}$ & Katara et al. (2010) \\
\hline 6 & BSq6.2i & СТ9993-5-10-1 M & $\begin{array}{l}154 \text { DH lines (CT9993-5-10-1 } \\
M(R) \text { and IR62266-42-6-2 (S)) }\end{array}$ & $\begin{array}{l}\text { Field evaluation without artificial } \\
\text { inoculation (Inceptisol soil) }\end{array}$ & Katara et al. (2010) \\
\hline 8 & BSq8.1i & СТ9993-5-10-1 M & $\begin{array}{l}154 \mathrm{DH} \text { lines (CT9993-5-10-1 } \\
\mathrm{M}(\mathrm{R}) \text { and IR62266-42-6-2 (S)) }\end{array}$ & $\begin{array}{l}\text { Field evaluation without artificial } \\
\text { inoculation (Inceptisol soil) }\end{array}$ & Katara et al. (2010) \\
\hline 8 & $B S q 8.2 \mathrm{~V}$ & СТ9993-5-10-1 M & $\begin{array}{l}154 \mathrm{DH} \text { lines (CT9993-5-10-1 } \\
\mathrm{M}(\mathrm{R}) \text { and IR62266-42-6-2 (S)) }\end{array}$ & $\begin{array}{l}\text { Field evaluation without artificial } \\
\text { inoculation (Vertisol soil) }\end{array}$ & Katara et al. (2010) \\
\hline 9 & $q B S 9$ & Tadukan & $\begin{array}{l}110 \text { RILs (Tadukan (R) } \\
\text { and Hinohikari (S)) }\end{array}$ & $\begin{array}{l}\text { Inoculation of 18-day-old-plants } \\
\text { in greenhouse }\end{array}$ & Sato et al. (2008a) \\
\hline 9 & (QTL) & Kasalath & $\begin{array}{l}39 \text { CSSLs (Donor: Kasalath (R), } \\
\text { Recipient: Koshihikari (S)) }\end{array}$ & $\begin{array}{l}\text { Inoculation of 18-day-old-plants } \\
\text { in greenhouse }\end{array}$ & Sato et al. (2008b) \\
\hline 9 & $B S q 9.1 \mathrm{v}$ & IR62266-42-6-2 & $\begin{array}{l}154 \mathrm{DH} \text { lines (CT9993-5-10-1 } \\
\mathrm{M}(\mathrm{R}) \text { and IR62266-42-6-2 (S)) }\end{array}$ & $\begin{array}{l}\text { Field evaluation without artificial } \\
\text { inoculation (Vertisol soil) }\end{array}$ & Katara et al. (2010) \\
\hline 11 & BSq11.1v\&i & СТ9993-5-10-1 M & $\begin{array}{l}154 \mathrm{DH} \text { lines (CT9993-5-10-1 } \\
\mathrm{M}(\mathrm{R}) \text { and IR62266-42-6-2 (S)) }\end{array}$ & $\begin{array}{l}\text { Field evaluation without artificial } \\
\text { inoculation (Vertisol and Inceptisol soils) }\end{array}$ & Katara et al. (2010) \\
\hline 11 & qBS11 & Tadukan & $\begin{array}{l}110 \text { RILs (Tadukan (R) } \\
\text { and Hinohikari (S)) }\end{array}$ & $\begin{array}{l}\text { Inoculation of 18-day-old-plants } \\
\text { in greenhouse }\end{array}$ & Sato et al. (2008a) \\
\hline 11 & qBSfR11 & Tadukan & $\begin{array}{l}110 \text { RILs (Tadukan (R) } \\
\text { and Hinohikari (S)) }\end{array}$ & $\begin{array}{l}\text { Field evaluation at } 113 \text { days after } \\
\text { transplanting by promoting disease } \\
\text { with inoculated spreader }\end{array}$ & Sato et al. (2015) \\
\hline 11 & $B S q 11.2 v$ & IR62266-42-6-2 & $\begin{array}{l}154 \mathrm{DH} \text { lines (CT9993-5-10-1 } \\
\mathrm{M}(\mathrm{R}) \text { and IR62266-42-6-2 (S)) }\end{array}$ & $\begin{array}{l}\text { Field evaluation without artificial } \\
\text { inoculation (Vertisol soil) }\end{array}$ & Katara et al. (2010) \\
\hline 12 & $B S q 12.1 \mathrm{~V}$ & СТ9993-5-10-1 M & $\begin{array}{l}154 \mathrm{DH} \text { lines (CT9993-5-10-1 } \\
\mathrm{M}(\mathrm{R}) \text { and IR62266-42-6-2 (S)) }\end{array}$ & $\begin{array}{l}\text { Field evaluation without artificial } \\
\text { inoculation (Vertisol soil) }\end{array}$ & Katara et al. (2010) \\
\hline 12 & bs 1 & Dinorado & $\begin{array}{l}186 \text { F2 lines (Dinorado (R) } \\
\text { and IR36 (S)) }\end{array}$ & (not described in detail) & Banu et al. (2008) \\
\hline
\end{tabular}

${ }^{\mathrm{a}}$ QTLs written in bold font were detected in similar positions in several cultivars in different experiments. QTLs with designations followed by $v$ and/or i were identified on Vertisol and/or Inceptisol soil, respectively

${ }^{\mathrm{b}}$ CSSLS chromosome segment substitution lines, $D H$ doubled haploid, RIL recombinant inbred lines, $R$ resistant cultivar, $S$ susceptible cultivar

Leung et al. 2015). By a follow-up study, bs1 with significant SNP markers spanning a $1.3 \mathrm{Mb}$ region was identified (Leung et al. 2015). With this region, local haplotypes, consisting of 7 SNPs were associated with resistance and the 'resistant' haplotype was present in 2777 (93\%) of the 3000 accessions (Leung et al. 2015). According to the report, a possible explanation is that landraces or traditional varieties were selected for disease resistance (BS) or other traits tightly linked to this region by farmers long ago before modern rice breeding (Leung et al. 2015).

\section{Screening cultivars for resistance to bacterial seedling rot (BSR)}

Although the same organism (Burkholderia glumae) causes both BSR and BGR in rice, the number of reports 
of screening cultivars for resistance to BSR is smaller than that for BGR (Table 3). Goto (1982) developed an evaluation method for BSR in which a bacterial suspension is injected into the soil at germination. A total of 293 cultivars and breeding lines were screened in Japan using this method and variation in resistance level was observed, although no highly resistant cultivars or lines were found (Goto 1983a). Another study was conducted in Japan in which 17 cultivars were screened by inoculation of sterilized seeds, and 'Kujuu' was found to be resistant (Hirashima and Wakimoto 1983).

In recent years, damage by Burkholderia glumae has also become severe in the United States (Ham et al. 2010). In 2006, Sayler and colleagues inoculated 28-day-old plants and found that 'LM-1' and 'Drew' exhibited resistance to BSR based on disease lesion size and bacterial growth in planta (Sayler et al. 2006). In 2014, Wamishe and colleagues analyzed BSR resistance of 300 cultivars by needle inoculation of seedling leaves and found that lesion sizes were too inconsistent to be used to differentiate resistance levels among cultivars (Wamishe et al. 2014). Differences in evaluation methods could be the reason why common resistant cultivars were not detected across the reports summarized in Table 3.

\section{Screening cultivars for resistance to bacterial grain rot (BGR)}

The severity of BGR infection is affected by host susceptibility, inoculum density, humidity, and temperature (Goto 1983b; Tsushima 1996). In Japan, damage by BGR was often observed in southern areas until oxolinic acid was developed as an agricultural chemical for BGR control (Hikichi et al. 1989; Hikichi 1993a, b). In field observations over 7 years, six cultivars were found to be relatively resistant (Yokoyama and Okuhara 1987) (Table 4). By a different research group of 85 cultivars over 3 years, three showed moderate resistance in field observations (Yasunaga et al. 2002) (Table 4). In 1975, Goto and Watanabe analyzed nine cultivars by field evaluation of plants inoculated at the flowering stage.
They found that none showed complete resistance and classified the cultivars as relatively resistant, moderate, or susceptible (Goto and Watanabe 1975). Among them, three cultivars were reported to be relatively resistant. Later, Goto developed an evaluation method in which large numbers of plants were cultivated in the greenhouse and inoculated at the flowering stage (Goto 1982). Using this method, Goto analyzed 293 cultivars and breeding lines and found that resistance levels differed among the materials, although no highly resistant cultivars or lines were identified (Goto 1983a). Similar results were reported by other groups (Mogi and Tsushima 1985; Takita et al. 1988). In field evaluation at the flowering stage, Imbe and colleagues found that breeding line 'Saikai169' was more susceptible than 'Saikai170' even though both were derived from the same cross (Imbe et al. 1986). The authors speculated that resistance to BGR was genetically controlled. In a greenhouse screen of 14 wild rice species inoculated at flowering stage, 10 accessions (O. meridionalis, O. stapfii, O. australiensis, O. officinalis, O. grandiglumis, O. glaberrima (OG-2), O. rufipogon, O. longistaminata, O. punctata, and $O$. alta) were found to be resistant (Tsushima et al. 1989).

Although most evaluation for BGR resistance has involved inoculation at the flowering stage, other evaluation methods have been developed. One method is field evaluation by inoculation of bacterial suspension into the boots (i.e., onto panicles prior to emergence from the stem) with a syringe (Prabhu and Bedendo 1988; Wasano and Okuda 1994). By this method, six Japanese cultivars and six cultivars from other countries were found to be resistant (Wasano and Okuda 1994), and in Brazil, cultivars 'Limeira' and 'Iguape Redondo' were found to be resistant (Prabhu and Bedendo 1988). Yet another method of evaluation is cut-panicle inoculation, which is based on the 'cut-spike' test developed for the evaluation of Fusarium head blight resistance in barley (Takeda and Heta 1989; Hori et al. 2005). To minimize environmental variation at the time of inoculation, this

Table 3 Previous reports of screening cultivars and breeding lines for resistance to bacterial seedling rot (BSR)

\begin{tabular}{|c|c|c|c|c|c|}
\hline Year & Country $^{a}$ & $\begin{array}{l}\text { Resistant cultivars and breeding } \\
\text { lines }\end{array}$ & $\begin{array}{l}\text { Number of screened } \\
\text { cultivars or lines }\end{array}$ & Evaluation method & Reference(s) \\
\hline 1983 & Japan & $\begin{array}{l}\text { (Resistance levels differed among } \\
\text { the materials, although no highly } \\
\text { resistant cultivars/lines were found.) }\end{array}$ & 293 & $\begin{array}{l}\text { Injection of bacterial suspension into } \\
\text { soil at germination }\end{array}$ & Goto $(1982,1983 a)$ \\
\hline 1983 & Japan & Kujuu & 17 & Inoculation of sterilized seeds & $\begin{array}{l}\text { Hirashima and } \\
\text { Wakimoto (1983) }\end{array}$ \\
\hline 2006 & USA & LM-1, Drew & 6 & Inoculation of 28-day-old-plants & Sayler et al. (2006) \\
\hline 2014 & USA & $\begin{array}{l}\text { (Lesion sizes were too inconsistent } \\
\text { to be used to differentiate resistance } \\
\text { levels among cultivars.) }\end{array}$ & 300 & Seedlings were needle inoculated. & Wamishe et al. (2014) \\
\hline
\end{tabular}


Table 4 Previous reports of screening cultivars and breeding lines for resistance to bacterial grain rot (BGR)

\begin{tabular}{|c|c|c|c|c|c|}
\hline Year & Country $^{a}$ & Resistant cultivars and breeding lines & $\begin{array}{l}\text { Number of screened } \\
\text { cultivars or lines }\end{array}$ & Evaluation method & Reference(s) \\
\hline 1975 & Japan & Fukumasari, Tachikaze, Kinmaze & 9 & $\begin{array}{l}\text { Field evaluation (inoculation } \\
\text { at flowering stage) }\end{array}$ & Goto and Watanabe (1975) \\
\hline 1983 & Japan & $\begin{array}{l}\text { (Resistance levels differed among } \\
\text { the materials, although no highly } \\
\text { resistant cultivars/lines were found.) }\end{array}$ & 293 & $\begin{array}{l}\text { Greenhouse evaluation } \\
\text { (inoculation at flowering stage) }\end{array}$ & Goto $(1982,1983 a)$ \\
\hline 1985 & Japan & $\begin{array}{l}\text { (No source of complete resistance } \\
\text { was identified.) }\end{array}$ & 11 & $\begin{array}{l}\text { Field evaluation (inoculation } \\
\text { at flowering stage) }\end{array}$ & Mogi and Tsushima (1985) \\
\hline 1986 & Japan & $\begin{array}{l}\text { (Saikai169 identified as a } \\
\text { susceptilble line) }\end{array}$ & 6 & $\begin{array}{l}\text { Field evaluation (inoculation } \\
\text { at flowering stage) }\end{array}$ & Imbe et al. (1986) \\
\hline 1987 & Japan & $\begin{array}{l}\text { Nihonmasari, Koganebare, Mineasahi, } \\
\text { Toyotama, Nishihomare, Kougyoku }\end{array}$ & 20 & $\begin{array}{l}\text { Field observation without artificial } \\
\text { inoculation over } 7 \text { years }\end{array}$ & Yokoyama and Okuhara (1987) \\
\hline 1987 & China & KaohsiungS.7 & 21 & $\begin{array}{l}\text { Field evaluation (inoculation } \\
\text { before flowering stage) }\end{array}$ & Chien and Chang (1987) \\
\hline 1988 & Japan & $\begin{array}{l}\text { (Resistance levels differed between } \\
\text { cultivars, although no highly resistant } \\
\text { cultivars were found.) }\end{array}$ & 427 & $\begin{array}{l}\text { Field evaluation (inoculation } \\
\text { at flowering stage) }\end{array}$ & Takita et al. (1988) \\
\hline 1988 & Brazil & Limeira, Iguape Redondo & 19 & $\begin{array}{l}\text { Field Evaluation (inoculation } \\
\text { of bacterial suspension into } \\
\text { boots by syringe) }\end{array}$ & Prabhu and Bedendo (1988) \\
\hline 1989 & Japan & $\begin{array}{l}\text { O. meridionalis, O. stapfii, O. australiensis, } \\
\text { O. officinalis, O. grandiglumis, } \\
\text { O. glaberrima (OG-2), O. rufipogon, } \\
\text { O. longistaminata, O. punctata, O. alta }\end{array}$ & 14 & $\begin{array}{l}\text { Evaluation of wild rice accessions } \\
\text { in greenhouse (inoculation } \\
\text { at flowering stage) }\end{array}$ & Tsushima et al. (1989) \\
\hline 1989 & Japan & Akuranboda, Col 155 & 22 & $\begin{array}{l}\text { Field evaluation (inoculation } \\
\text { at flowering stage) and } \\
\text { cut-panicle inoculation }\end{array}$ & Miyagawa and Kimura (1989) \\
\hline \multirow[t]{2}{*}{1994} & \multirow[t]{2}{*}{ Japan } & $\begin{array}{l}\text { Resistant Japanese cultivars: Sasanishiki, } \\
\text { Kokuryoumiyako, Benisengoku, Jukkoku, } \\
\text { Mizuho, Kogyoku }\end{array}$ & \multirow[t]{2}{*}{129} & \multirow[t]{2}{*}{$\begin{array}{l}\text { Field Evaluation (inoculation } \\
\text { of bacterial suspension into } \\
\text { boots by syringe) }\end{array}$} & \multirow[t]{2}{*}{ Wasano and Okuda (1994) } \\
\hline & & $\begin{array}{l}\text { Resistant non-Japanese cultivars: } \\
\text { Palkeng, Century Patna, Belle Patna 9433, } \\
\text { Hybrid Pearl, Blue Bonnet 50, RD-23 }\end{array}$ & & & \\
\hline 2002 & Japan & Chikushi52, Chikushi41, Tsukushiwase & 85 & $\begin{array}{l}\text { Field observation without } \\
\text { artificial inoculation over } 3 \text { years }\end{array}$ & Yasunaga et al. (2002) \\
\hline 2007 & USA & Jupiter & 5 & $\begin{array}{l}\text { Field evaluation (inoculation } \\
\text { at flowering stage) }\end{array}$ & Nandakumar et al. (2007a) \\
\hline 2007 & USA & LM-1, LMT-1 & $(2)^{b}$ & $\begin{array}{l}\text { Field evaluation (inoculation } \\
\text { at flowering stage) }\end{array}$ & Groth et al. (2007) \\
\hline 2013 & Japan & $\begin{array}{l}\text { Kele, Kasalath, Jhona2, Jaguary, } \\
\text { Khau Mac Kho }\end{array}$ & 84 & Cut-panicle inoculation & Mizobuchi et al. (2013a) \\
\hline \multirow[t]{2}{*}{2014} & \multirow[t]{2}{*}{ USA } & $\begin{array}{l}14 \text { lines were identified as resistant, } \\
30 \text { lines as moderately resistant (2012) }\end{array}$ & 300 & $\begin{array}{l}\text { Field evaluation (inoculation } \\
\text { from boot split to flowering stage) } \\
\text { over } 2 \text { years }\end{array}$ & \multirow[t]{2}{*}{ Wamishe et al. (2014) } \\
\hline & & $\begin{array}{l}15 \text { lines were identified as resistant, } \\
53 \text { lines as moderately resistant (2013) }\end{array}$ & & & \\
\hline
\end{tabular}

${ }^{\mathrm{a}}$ Country where experiment was conducted

${ }^{\mathrm{b}} \mathrm{LM}-1$ and LMT-1 were selected from $1 \mathrm{~kg}$ of mutagenized seeds of Lemont irradiated with gamma radiation (250 Gy) from $60 \mathrm{Co}$

method entails the collection of panicles from fieldgrown plants and their inoculation under controlled conditions at the time of flowering (Miyagawa and Kimura 1989). Because the correlation coefficient between the disease rating obtained by cut-panicle inoculation and that obtained by pot inoculation is very high $(r=0.868)$, cut-panicle inoculation was recognized as a useful method for evaluating BGR resistance, and two out of 22 cultivars screened were found to be resistant (Miyagawa and Kimura 1989). By using a cut-panicle inoculation method, Mizobuchi and colleagues evaluated 84 cultivars, including 62 accessions from WRC [World Rice Collection of the National Institute of Agrobiological Sciences (NIAS) (Kojima et al. 2005)], and five cultivars including 'Kele' were 
found to be relatively resistant to BGR (Mizobuchi et al. 2013a).

In addition to the work on BGR in Japan, reports from other countries are increasing. All of the evaluations summarized here involved inoculation of field-grown plants at or before flowering. In China, 'Kaohsiung S.7' was found to be resistant (Chien and Chang 1987). In the United States, 'Jupiter' (Nandakumar et al. 2007a) and two other lines (Groth et al. 2007) were identified as resistant; the latter two lines were selected from mutagenized seeds of 'Lemont' irradiated with gamma radiation ( $250 \mathrm{~Gy}$ ) from Cobalt-60. Recently in the United States, Wamishe and colleagues analyzed 300 entries in the Uniform Regional Rice Nursery (URRN) and Arkansas Rice Performance Trials (ARPT) over 2 years; in these tests, over 10 entries showed resistance and over 30 entries showed moderate levels of resistance (Wamishe et al. 2014).
Analysis of QTLs for resistance to bacterial seedling rot (BSR) and bacterial grain rot (BGR)

Although Burkholderia glumae causes both BSR and BGR, no correlation between resistance to the two diseases was observed in an early study (Goto 1983a). Similarly, cultivars partially resistant to BGR (Mizobuchi et al. 2013a) were not always resistant to BSR (Mizobuchi et al. in preparation). Therefore, the molecular mechanisms for resistance to BSR appear to be different from those for resistance to BGR.

To date, only one QTL for resistance to BSR has been identified (Mizobuchi et al. 2013b). This QTL (qRBS1, quantitative trait locus to resistance to bacterial seedling rot 1) was found on chromosome 10 by using CSSLs derived from a cross between 'Nona Bokra' (resistant) and 'Koshihikari' (susceptible) (Table 5). qRBS1 was mapped in the region of $R M 24930-R M 24944$ and located by

Table 5 QTLs for resistance to bacterial seedling rot (BSR) and bacterial grain rot (BGR)

\begin{tabular}{|c|c|c|c|c|c|}
\hline Chromosome & QTL & $\begin{array}{l}\text { Source of resistance } \\
\text { allele }\end{array}$ & $\begin{array}{l}\text { Materials used for QTL } \\
\text { analysis }^{\mathrm{a}}\end{array}$ & Phenotyping method & Reference(s) \\
\hline \multicolumn{6}{|c|}{ Resistance to BSR } \\
\hline 10 & RBG1 (qRBS1) & Nona Bokra & $\begin{array}{l}44 \text { CSSLs (Donor: Nona } \\
\text { Bokra (R), Recipient: } \\
\text { Koshihikari (S)) }\end{array}$ & Inoculation of sterilized seeds & Mizobuchi et al. (2013b) \\
\hline \multicolumn{6}{|c|}{ Resistance to BGR } \\
\hline 1 & RBG2 & Kele & $\begin{array}{l}110 \text { BILs (Kele (R) } \\
\text { and Hitomebore (S)) }\end{array}$ & Modified cut-panicle inoculation ${ }^{b}$ & $\begin{array}{l}\text { Mizobuchi et al. (2013a, } \\
\text { 2015) }\end{array}$ \\
\hline 1 & $q B P B-1-1$ & TeQing & $\begin{array}{l}300 \text { RILs (TeQing (R) } \\
\text { and Lemont (S)) }\end{array}$ & $\begin{array}{l}\text { Field evaluation (inoculation from } \\
\text { full boot stage to flowering stage) }\end{array}$ & Pinson et al. (2010) \\
\hline 1 & $q B P B-1-2$ & TeQing & $\begin{array}{l}300 \text { RILs (TeQing (R) } \\
\text { and Lemont (S)) }\end{array}$ & $\begin{array}{l}\text { Field evaluation (inoculation from } \\
\text { full boot stage to flowering stage) }\end{array}$ & Pinson et al. (2010) \\
\hline 1 & aBPB1-3 & Lemont & $\begin{array}{l}300 \text { RILs (TeQing (R) } \\
\text { and Lemont (S)) }\end{array}$ & $\begin{array}{l}\text { Field evaluation (inoculation from } \\
\text { full boot stage to flowering stage) }\end{array}$ & Pinson et al. (2010) \\
\hline 2 & $a B P B-2-1$ & Lemont & $\begin{array}{l}300 \text { RILs (TeQing (R) } \\
\text { and Lemont (S)) }\end{array}$ & $\begin{array}{l}\text { Field evaluation (inoculation from } \\
\text { full boot stage to flowering stage) }\end{array}$ & Pinson et al. (2010) \\
\hline 2 & $q B P B-2-2$ & TeQing & $\begin{array}{l}300 \text { RILs (TeQing (R) } \\
\text { and Lemont (S)) }\end{array}$ & $\begin{array}{l}\text { Field evaluation (inoculation from } \\
\text { full boot stage to flowering stage) }\end{array}$ & Pinson et al. (2010) \\
\hline 3 & $q B P B-3-1$ & TeQing & $\begin{array}{l}300 \text { RILs (TeQing (R) } \\
\text { and Lemont (S)) }\end{array}$ & $\begin{array}{l}\text { Field evaluation (inoculation from } \\
\text { full boot stage to flowering stage) }\end{array}$ & Pinson et al. (2010) \\
\hline 3 & $q B P B-3-2$ & Lemont & $\begin{array}{l}300 \text { RILs (TeQing (R) } \\
\text { and Lemont (S)) }\end{array}$ & $\begin{array}{l}\text { Field evaluation (inoculation from } \\
\text { full boot stage to flowering stage) }\end{array}$ & Pinson et al. (2010) \\
\hline 7 & $q B P B-7$ & TeQing & $\begin{array}{l}300 \text { RILs (TeQing (R) } \\
\text { and Lemont (S)) }\end{array}$ & $\begin{array}{l}\text { Field evaluation (inoculation from } \\
\text { full boot stage to flowering stage) }\end{array}$ & Pinson et al. (2010) \\
\hline 8 & $9 B P B-8-1$ & TeQing & $\begin{array}{l}300 \text { RILs (TeQing (R) } \\
\text { and Lemont (S)) }\end{array}$ & $\begin{array}{l}\text { Field evaluation (inoculation from } \\
\text { full boot stage to flowering stage) }\end{array}$ & Pinson et al. (2010) \\
\hline 8 & $q B P B-8-2$ & Lemont & $\begin{array}{l}300 \text { RILs (TeQing (R) } \\
\text { and Lemont (S)) }\end{array}$ & $\begin{array}{l}\text { Field evaluation (inoculation from } \\
\text { full boot stage to flowering stage) }\end{array}$ & Pinson et al. (2010) \\
\hline 10 & $9 B P B-10$ & TeQing & $\begin{array}{l}300 \text { RILs (TeQing (R) } \\
\text { and Lemont (S)) }\end{array}$ & $\begin{array}{l}\text { Field evaluation (inoculation from } \\
\text { full boot stage to flowering stage) }\end{array}$ & Pinson et al. (2010) \\
\hline 11 & $q B P B-11$ & TeQing & $\begin{array}{l}300 \text { RILs (TeQing (R) } \\
\text { and Lemont (S)) }\end{array}$ & $\begin{array}{l}\text { Field evaluation (inoculation from } \\
\text { full boot stage to flowering stage) }\end{array}$ & Pinson et al. (2010) \\
\hline
\end{tabular}

${ }^{a}$ BILs backcross inbred lines, CSSLS chromosome segment substitution lines, RILs recombinant inbred lines, $R$ resistant cultivar, $S$ susceptible cultivar ${ }^{\mathrm{b}}$ Spikelets were inoculated 1 day after anthesis 
substitution mapping in a 393-kb interval of the short arm of chromosome 10 in the 'Nipponbare' genome reference sequence (Mizobuchi et al. 2013b). This QTL explained $22 \%$ of the total phenotypic variation for resistance to $B S R$ in an $F_{5}$ population derived from a cross between a resistant CSSL and 'Koshihikari', and was thought to be involved in a key process for resistance to Burkholderia glumae at the seedling stage. Because $q R B S 1$ is the first fine-mapped QTL related to resistance to Burkholderia glumae, it was renamed as RBG1 (Resistance to Burkholderia glumae 1) (Mizobuchi et al. 2013b; Mizobuchi et al. 2015). According to the QTL Annotation Rice Online Database (Q-TARO) (Yonemaru et al. 2010), no QTLs related to disease resistance have been found in the region of RM24930RM24944. Therefore, RBG1 appears to be a novel QTL.

On the other hand, a large number of QTLs for resistance to BGR have been identified (Table 5). (Pinson et al. 2010) used a set of RILs derived from a cross between 'TeQing' (resistant) and 'Lemont' (susceptible) to identify QTLs conferring resistance to BGR at the flowering stage in 2001 and 2002. The evaluation method involved repeated inoculation of panicles in the field from full boot stage to flowering stage. Using these RILs, 12 QTLs were identified on seven chromosomes (Table 5). Among these QTLs, three ( $q B P B-1-3, q B P B-3-1$ and $q B P B-3-2)$ were statistically significant in both years. The favorable alleles for eight of the QTLs were derived from 'TeQing'; those for the other four QTLs were derived from 'Lemont'. Four QTLs were co-located with QTLs previously associated with resistance to other diseases: $q B P B-2-1$ was mapped near a QTL for resistance to sheath blight (Pinson et al. 2005), qBPB-2-2 was mapped near QTLs for resistance to blast (Tabien et al. 2002) and bacterial leaf blight ( $\mathrm{Li}$ et al. 1999), $q B P B-3-1$ was mapped near QTLs for resistance to blast and sheath blight, and $q B P B-8-2$ was mapped near QTLs for resistance to sheath blight and bacterial leaf blight. A major QTL, $q B P B-3-1$, which accounted for approximately $14 \%$ of phenotypic variation in the mean of the 2001 and 2002 annual averages, was found to be co-located with a QTL for heading date. Two other QTLs ( $q B P B-8-2$ and $q B P B-$ 10) were also co-located with QTLs for late flowering. Because late-flowering panicles are subjected to cooler temperatures that are less conductive to disease development during grain fill, it is possible that the genetic effects of the heading-related QTLs affected the disease scoring. Pinson et al. (2010) concluded that the data could not distinguish between pleiotropy and close linkage of the QTLs identified previously.

In another study, a major QTL for BGR resistance was mapped on the long arm of chromosome 1 using backcross inbred lines (BILs) derived from a cross between 'Kele' (resistant) and 'Hitomebore' (susceptible) (Mizobuchi et al. 2013a). 'Kele' and 'Hitomebore' were selected for BIL development and genetic analysis after prescreening of 84 cultivars. A modified cut-panicle inoculation method was applied to minimize environmental effects: specifically, panicles containing only spikelets at one day after anthesis were harvested and inoculated. To search for QTLs associated with BGR resistance, the ratio of diseased spikelets (RDS, an index reflecting both quantity and severity of infection) and the ratio of diseased spikelet area (RDSA) were measured. In the BILs, the detected QTL explained $25.7 \%$ and $12.1 \%$ of the total phenotypic variation in RDS and RDSA, respectively, and the 'Kele' allele increased BGR resistance. On the other hand, no QTLs for agronomic traits such as culm length, panicle length, panicle number, spikelet length, spikelet width or heading date were detected close to the QTL for RDS and RDSA. In a follow-up study (Mizobuchi et al. 2015), substitution mapping using homozygous recombinant and nonrecombinant plants demonstrated that the QTL, designated as RBG2, was located in a 502-kb interval defined by RM1216 and RM11727 on the long arm of chromosome 1 . On the basis of map information, $R B G 1$ seems to be different from $q B P B-10$, and $R B G 2$ seems to be different from $q B P B-1-1, q B P B-1-2$ and $q B P B-1-3$.

\section{Conclusions}

As reviewed here, several QTLs for resistance to BS, BSR and BGR have been detected owing to improvements in evaluation methods for disease resistance and to recent progress in rice molecular genetics. As an example of the former, a seedling evaluation method for BS resistance was developed that enabled detection of several QTLs, including qBS11 (Sato et al. 2008a; Sato et al. 2008b). In a later study, $q B S 11$ was reconfirmed as qBSfR11, a QTL for field resistance to BS (Sato et al. 2015). RBG2, which confers resistance to BGR, was identified by a modified cut-panicle inoculation method (Mizobuchi et al. 2013a) that minimizes environmental influences such as humidity and temperature. Importantly, no QTL alleles for agronomic traits such as heading date were linked to $R B G 2$, suggesting that the effects of this locus might be detectable regardless of environmental conditions or other agronomic traits. It will be necessary to confirm the effectiveness of $R B G 2$ under field conditions in order to use it for breeding resistant cultivars.

Advanced-backcross progeny such as CSSLs can be very useful for genetic analysis (Ebitani et al. 2005; Takai et al. 2007; Fukuoka et al. 2010a; Fukuoka et al. 2010b). Because each CSSL has only one or a few segment substitutions, it is possible to detect QTLs with minor effects contained within the substituted segments. By using CSSLs, RBG1 (resistance to BGR) and a QTL for BS resistance were detected (Sato et al. 2008b; Mizobuchi et al. 2013b). 
Recent progress in genomics has enhanced understanding of the genetic basis of agronomic traits, and development of crops with the desired traits could enhance adaptation to climate change or mitigate its effects (Yamamoto et al. 2009; Abberton et al. 2016; Kole et al. 2015). For example, genome-wide identification of single-nucleotide polymorphisms between BGR-resistant cultivar 'Jupiter' (Nandakumar et al. 2007a) and a susceptible control cultivar has been conducted as a step toward fine mapping the resistance in this line (Shrestha et al. 2014). Although several QTLs have been fine mapped, none have yet been cloned, so the mechanisms underlying the QTLs reviewed in this paper are still unknown. Isolation and characterization of RBG1 (for resistance to BSR) is now underway (Mizobuchi et al. unpublished data). Isolation of $R B G 1$ and other genes underlying disease resistance QTLs will elucidate the genetic mechanisms of resistance.

The race specificity of the host resistance to BS, BSR and BGR is critical for the utilization of resistance QTLs in varietal improvement. By a screen of 80 cultivars in 1974, eight cultivars including 'Tadukan' were found to be resistant to many strains of BS (Ohata and Kubo 1974; Ohata 1989). In a later study, $q B S 11$ from Tadukan was reconfirmed as $q B S f R 11$, a QTL for field resistance to BS (Sato et al. 2008a; Sato et al. 2015). qBS11 was found by inoculation of a strain (D6-2), while a different stain was isolated from the field in the research of qBSfR11. Therefore qBSfR11 seems to be a QTL without race-specificity. NIL harboring RBG1 (for resistance to BSR) seems to be multiple resistance to several strains, indicating RBG1 is a QTL without race-specificity (Mizobuchi et al. unpublished data). On the other hand, the presence of the race specificity of $R B G 2$ (for resistance to BGR) is unknown.

Although BSR and BGR are caused by the same pathogen (Burkholderia glumae), no cultivars were found as resistance to BSR and BGR. However, the number of reports of screening cultivars for resistance to BSR is much smaller than that for BGR. Thus the correlation of $R B G$ in seedling and panicle stages could be underestimated. Characterization of $R B G 1$ and $R B G 2$ is now underway (Mizobuchi et al. unpublished data).

Is it possible to breed 'ideal' resistant cultivars by using only the QTLs described in this paper? Of course, the answer is no. Although several major QTLs have been detected $-q B S 9$ and $B S q 9.1, q B S 11$ and $q B S f R 11$ for BS, RBG1 for BSR and RBG2 for BGR-none of them explained over $30 \%$ of the phenotypic variation in the QTL analysis. Thus, it will be necessary to identify new QTLs from different sources for gene pyramiding. A recent study (Fukuoka et al. 2015) confirmed that gene pyramiding enhances durable blast disease resistance in rice. In addition, the factors associated with resistance to BSR and BGR seem to be different, so it will be necessary to combine RBG1, RBG2 and additional QTLs for stable resistance to both diseases. Because BS, BSR and BGR are common diseases that have been increased by global warming, the final goal is to pyramid QTLs for resistance into elite germplasm as a means of developing cultivars with resistance to all of these important diseases.

\section{Competing interests}

The authors declare that they have no competing interests.

\section{Authors' contributions}

RM wrote the first draft. SF, ST and MY added valuable comments. HS completed the manuscript writing. All authors read and approved the final manuscript.

\section{Acknowledgements}

This work was supported by grants from the Ministry of Agriculture, Forestry and Fisheries of Japan (Project for Climate Change, Rice-2006 and Rice-1201) and by JSPS KAKENHI Grant Number 15KO7264.

\section{Author details}

${ }^{1}$ National Institute of Agrobiological Sciences, 2-1-2 Kannondai, Tsukuba, Ibaraki 305-8602, Japan. ${ }^{2}$ National Institute for Agro-Environmental Sciences, 3-1-3 Kannondai, Ibaraki 305-8604, Japan. ${ }^{3}$ NARO Institute of Crop Science (NICS), 2-1-18 Kannondai, Tsukuba, Ibaraki 305-8518, Japan. ${ }^{4}$ National Agriculture and Food Research Organization, Kyushu Okinawa Agricultural Research Center (NARO/KARC), 496 Izumi, Chikugo, Fukuoka 833-0041, Japan.

Received: 30 January 2016 Accepted: 4 May 2016

Published online: 13 May 2016

\section{References}

Abberton M, Batley J, Bentley A, Bryant J, Cai H, Cockram J, Oliveira AC, Cseke LJ, Dempewolf H, Pace CD, Edwards D, Gepts P, Greenland A, Hall AE, Henry R, Hori K, Howe GT, Hughes S, Humphreys M, Lightfoot D, Marshall A, Mayes S, Nguyen HT, Ogbonnaya FC, Ortiz R, Paterson AH, Tuberosa R, Valliyodan B, Varshney RK, Yano M (2016) Global agricultural intensification during climate change: a role for genomics. Plant Biotechnol J 14:1095-1098

Adair CR (1941) Inheritance in rice of reaction to Helminthosporium oryzae and Cercospora oryzae. Technical Bulletin, United States Department of Agriculture, Washington, D.C. No.772:1-18

Balal M, Omar RA, El-Khadem MM, Aidy IR (1979) Inheritance of resistance to the brown spot disease of rice, Cocoliobolus miyabeanus. Agric Res Rev 57:119-133

Banu SP, Meah B, Ali A, Brar DS, Leung H, Cruz CV (2008) Inheritance and molecular mapping for brown spot disease resistance in rice. J Plant Pathol 90(S2):295

Barnwal MK, Kotasthane A, Magculia N, Mukherjee PK, Savary S, Sharma AK, Singh HB, Singh US, Sparks AH, Variar M, Zaidi N (2013) A review on crop losses, epidemiology and disease management of rice brown spot to identify research priorities and knowledge gaps. Eur J Plant Pathol 136(3):443-457

Chakrabarti NK (2001) Epidemiology and disease management of brown spot of rice in India. In: Major Fungal Diseases of Rice Recent Advances. Kluwer Academic Publishers. Printed in the Netherlands. pp293-306

Chien CC, Chang YC (1987) The susceptibility of rice plants at different growth stages and 21 commercial rice varieties to Pseudomonas glumae. J Agric Res China 36:302-310

Cottyn B, Cerez MT, VanOutryve MF, Barroga J, Swings J, Mew TW (1996a) Bacterial diseases of rice. 1. Pathogenic bacteria associated with sheath rot complex and grain discoloration of rice in the Philippines. Plant Dis 80(4):429-437

Cottyn B, VanOutryve MF, Cerez MT, DeCleene M, Swings J, Mew TW (1996b) Bacterial diseases of rice. 2. Characterization of pathogenic bacteria associated with sheath rot complex and grain discoloration of rice in the Philippines. Plant Dis 80(4):438-445

Dallagnol LJ, Rodrigues FA, Mielli MVB, Ma JF (2014) Rice grain resistance to brown spot and yield are increased by silicon. Trop Plant Pathol 39(1):56-63

Datnoff LE, Raid RN, Snyder GH, Jones DB (1991) Effect of calcium silicate on blast and brown spot intensities and yields of rice. Plant Dis 75(7):729-732

Datnoff LE, Deren CW, Snyder GH (1997) Silicon fertilization for disease management of rice in Florida. Crop Prot 16(6):525-531 
Deren CW, Datnoff LE, Snyder GH, Martin FG (1994) Silicon concentration, disease response, and yield components of rice genotypes grown on flooded organic histosols. Crop Sci 34(3):733-737

Ebitani T, Takeuchi Y, Nonoue Y, Yamamoto T, Takeuchi K, Yano M (2005) Construction and evaluation of chromosome segment substitution lines carrying overlapping chromosome segments of indica rice cultivar 'Kasalath' in a genetic background of japonica elite cultivar 'Koshihikari'. Breeding Sci 55(1):65-73

Eruotor PG (1986) Varietal reaction of rice to isolates of Cochliobolus miyabeanus. Indian Phytopath 39:62-64

Fukuoka S, Ebana K, Yamamoto T, Yano M (2010a) Integration of genomics into rice breeding. Rice 3(2-3):131-137

Fukuoka S, Nonoue Y, Yano M (2010b) Germplasm enhancement by developing advanced plant materials from diverse rice accessions. Breeding Sci 60(5):509-517

Fukuoka S, Saka N, Mizukami Y, Koga H, Yamanouchi U, Yoshioka Y, Hayashi N, Ebana K, Mizobuchi R, Yano M (2015) Gene pyramiding enhances durable blast disease resistance in rice. Sci Rep Uk 5:7773

Goel RK, Bala R, Singh K (2006) Genetic characterization of resistance to brown leaf spot caused by Drechslera oryzae in some wild rice (Oryza sativa) lines. Indian Journal of Agricultural Sciences 76(11):705-707.

Goto T (1982) Inoculation methods for resistance to bacterial seedling rot and grain rot in Burkholderia glumae. (in Japanese). Ann Phytopathol Soc Jpn 48:373

Goto T (1983a) Resistance to Burkholderia glumae of lowland rice cultivars and promising lines in Japan. (in Japanese). Ann Phytopathol Soc Jpn 49:410

Goto T (1983b) Rice bacterial grain rot, occurrence and research. (in Japanese). Shokubutsu Boeki 37:395-399

Goto K, Ohata K (1956) New bacterial diseases of rice (brown stripe and grain rot). Ann Phytopathol Soc Jpn 21:46-47

Goto T, Watanabe B (1975) Varietal resistance to bacterial grain rot of rice, caused by Pseudomonas glumae (in Japanese). Proc Assoc PI Prot Kyushu 21:141-143

Goto T, Nishiyama K, Ohata K (1987) Bacteria causing grain rot of rice. Ann Phytopathol Soc Jpn 53:141-149

Groth DE, Linscombe SD, Sha X (2007) Registration of two disease-resistant germplasm lines of rice. J Plant Regist 1(1):63-64

Ham J, Barphagha I, Karki H, Shrestha B, Melanson R, Chen R (2010) Identification of novel regulatory genes of Burkholderia glumae for virulence factors. Phytopathology 100(6):S47-S47

Ham J, Karki HS, Shrestha B, Barphagha IK, Melanson RA, Chen R, Groth DE, Sha X, Utomo H, Subudhi P, Rush MC (2011a) Molecular genetic and genomic studies on bacterial panicle blight of rice and its causative agent Burkholderia glumae. Phytopathology 101(6):S266-S266

Ham JH, Melanson RA, Rush MC (2011b) Burkholderia glumae: next major pathogen of rice? Mol Plant Pathol 12(4):329-339

Hikichi Y (1993a) Antibacterial activity of oxolinic acid on Pseudomonas glumae. Ann Phytopathol Soc Jpn 59:369-374

Hikichi Y (1993b) Relationship between population dynamics of Pseudomonas glumae on rice plants and disease severity of bacterial grain rot of rice. J Pestic Sci 18:319-324

Hikichi Y, Noda C, Shimizu K (1989) Oxolic acid. Jpn Pestic Infect 55:21-23

Hirashima K, Wakimoto $T$ (1983) The differences of cultivars in resistance to bacterial seedling rot in rice. (in Japanese). Ann Phytopathol Soc Jpn 49:411

Hori K, Kobayashi T, Sato K, Takeda K (2005) QTL analysis of Fusarium head blight resistance using a high-density linkage map in barley. Theor Appl Genet 111(8):1661-1672

Hossain M, Khalequzzaman KM, Mollah MRA, Hussain MA, Rahim MA (2004) Reaction of breeding lines/cultivars of rice against brown spot and blast under field condition. Asian J Plant Sci 3:614-617

Hu KM, Qiu DY, Shen XL, Li XH, Wang SP (2008) Isolation and manipulation of quantitative trait loci for disease resistance in rice using a candidate gene approach. Mol Plant 1(5):786-793

Imbe T, Tsushima S, Nishiyama H (1986) Varietal resistance of rice to bacterial grain rot and screening method. Proc Assoc PI Prot Kyushu 32:17-19

IPCC (2014) Climate change 2014, synthesis report, summary for policymakers. https://www.ipcc.ch/report/ar5/. Accessed 12 May 2016.

Jeong Y, Kim J, Kim S, Kang Y, Nagamatsu T, Hwang I (2003) Toxoflavin produced by Burkholderia glumae causing rice grain rot is responsible for inducing bacterial wilt in many field crops. Plant Dis 87(8):890-895

JPPA (2014) Epidemic and controlling areas in 2013. In: Japan Plant Protection Association (ed) Catalogue of agricultural chemicals, Tokyo., pp 572-574

Juroszek P, von Tiedemann A (2015) Linking plant disease models to climate change scenarios to project future risks of crop diseases: a review. J Plant Dis Protect 122(1):3-15
Katara JL, Sonah H, Deshmukh RK, Chaurasia R, Kotasthane AS (2010) Molecular analysis of QTLs associated with resistance to brown spot in rice (Oryza sativa L.). Indian J Genet PI Br 70(1):17-21

Kojima Y, Ebana K, Fukuoka S, Nagamine T, Kawase M (2005) Development of an RFLP-based rice diversity research set of germplasm. Breeding Sci 55(4):431-440

Kole C, Muthamilarasan M, Henry R, Edwards D, Sharma R, Abberton M, Batley J, Bentley A, Blakeney M, Bryant J, Cai HW, Cakir M, Cseke LJ, Cockram J, de Oliveira AC, De Pace C, Dempewolf H, Ellison S, Gepts P, Greenland A, Hall A, Hori K, Hughes S, Humphreys MW, lorizzo M, Ismail AM, Marshall A, Mayes S, Nguyen HT, Ogbonnaya FC, Ortiz R, Paterson AH, Simon PW, Tohme J, Tuberosa R, Valliyodan B, Varshney RK, Wullschleger SD, Yano M, Prasad M (2015) Application of genomics-assisted breeding for generation of climate resilient crops: progress and prospects. Front Plant Sci 6:563

Kurita T, Tabei H (1967) On the pathogenic bacterium of bacterial grain rot of rice. Ann Phytopathol Soc Jpn 33:111

Kurita T, Tabei H, Sato T (1964) A few studies on factors associated with infection of bacterial grain rot of rice. Ann Phytopathol Soc Jpn 29:60

Leung H, Raghavan C, Zhou B, Oliva R, Choi IR, Lacorte V, Jubay ML, Cruz CV, Gregorio G, Singh RK, Ulat VJ, Borja FN, Mauleon R, Alexandrov NN, McNally KL, Hamilton RS (2015) Allele mining and enhanced genetic recombination for rice breeding. Rice 8:1-11

Li ZK, Luo L, Mei HW, Paterson AH, Zhao XZ, Zhong DB, Wang YP, Yu XQ, Zhu L, Tabien R, Stansel JW, Ying CS (1999) A "defeated" rice resistance gene acts as a QTL against a virulent strain of Xanthomonas oryzae pv. oryzae. Mol Gen Genet 261(1):58-63

Liu JL, Wang XJ, Mitchell T, Hu YJ, Liu XL, Dai LY, Wang GL (2010) Recent progress and understanding of the molecular mechanisms of the riceMagnaporthe oryzae interaction. Mol Plant Pathol 11(3):419-427

Luo J, Xie G, Li B, Lihui X (2007) First report of Burkholderia glumae isolated from symptomless rice seeds in China. Plant Dis 91(10):1363-1363

Misra AK (1985) Effect of intercepting populations of resistant cultivars on reducing brown spot disease build up in a susceptible rice cultivar. Indian Phytopath 38:66-69

Miyagawa H, Kimura T (1989) A test of rice varietal resistance to bacterial grain rot by inoculation on cut-spikes at anthesis. Chugoku Natl Agric Exp Stn 78:17-21

Mizobuchi R, Sato H, Fukuoka S, Tanabata T, Tsushima S, Imbe T, Yano M (2013a) Mapping a quantitative trait locus for resistance to bacterial grain rot in rice. Rice 6:13

Mizobuchi R, Sato H, Fukuoka S, Tsushima S, Imbe T, Yano M (2013b) Identification of qRBS1, a QTL involved in resistance to bacterial seedling rot in rice. Theor Appl Genet 126(9):2417-2425

Mizobuchi R, Sato H, Fukuoka S, Tsushima S, Yano M (2015) Fine mapping of RBG2, a quantitative trait locus for resistance to Burkholderia glumae, on rice chromosome 1. Mol Breeding 35:1

Mogi S, Tsushima S (1985) Varietal resistance to bacterial grain rot in rice, caused by Pseudomonas glumae. Kyushu Agric Res 47:103

Nagai I, Hara S (1930) On the inheritance of variegation disease in a strain of rice plant. Jpn J Genet 5:140-144

Nandakumar R, Rush M, Shahjahan A, O'Reilly K, Groth D (2005) Bacterial panicle blight of rice in the southern United States caused by Burkholderia glumae and B. gladioli. Phytopathology 95(6):S73

Nandakumar R, Bollich P, Groth D, Rush MC (2007a) Confirmation of the partial resistance of Jupiter rice to bacterial panicle blight caused by Burkholderia glumae through reduced disease and yield loss in inoculated field tests. Phytopathology 97(7):S82-S83

Nandakumar R, Rush MC, Correa F (2007b) Association of Burkholderia glumae and B. gladioli with panicle blight symptoms on rice in Panama. Plant Dis 91 (6):767

Nandakumar R, Shahjahan AKM, Yuan XL, Dickstein ER, Groth DE, Clark CA, Cartwright RD, Rush MC (2009) Burkholderia glumae and B. gladioli cause bacterial panicle blight in rice in the southern United States. Plant Dis 93(9):896-905

Ohata K (1989) Brown spot disease. (in Japanese). In: Rice Diseases. Zenkoku Nouson Kyouiku Kyoukai, Printed in Japan, pp 357-374

Ohata K, Kubo C (1974) Studies on the mechanism of disease resistance of rice varieties to Cochliobolus miyabeanus. (in Japanese). Bull Shikoku Agric Exp Stn 28:17-57

Ono K (1953) Morphological studies on blast and sesame leaf spot of rice plant. (in Japanese). Bull Hokuriku Natl Agric Exp Stn 2:1-77

Ou SH (1985) Rice diseases, 2nd edn. Commonwealth Micological Institute, Kew, UK, pp 1-380

Padmanabhan SY (1973) The great Bengal famine. Annu Rev Phytopathol 11:11-26

Pannu PPS, Chahal SS, Sharma VK, Kaur M, Bagga PS (2006) Occurrence of brown leaf spot of rice in Punjab, its effect on grain yield and its control. Indian Phytopath 59:190-193 
Pinson SRM, Capdevielle FM, Oard JH (2005) Confirming QTLs and finding additional loci conditioning sheath blight resistance in rice using recombinant inbred lines. Crop Sci 45(2):503-510

Pinson SRM, Shahjahan AKM, Rush MC, Groth DE (2010) Bacterial panicle blight resistance QTLs in rice and their association with other disease resistance loci and heading date. Crop Sci 50(4):1287-1297

Prabhu AS, Bedendo IP (1988) Glume blight of rice in Brazil: etiology, varietal reaction and loss estimates. Trop Pest Manag 34:85-88

Reddy CS, Laha GS, Prasad MS, Krichnaveni D, Castilla NP, Nelson A (2010) Characterizing multiple linkages between individual diseases, crop health syndromes, germplasm deployment and rice production situations in India. Field Crop Res 120:241-253

Satija A, Chahal SS, Pannu PPS (2005) Evaluation of rice genotypes against brown spot disease. Plant Dis Res 20:163-164

Sato H, Ando I, Hirabayashi H, Takeuchi Y, Arase S, Kihara J, Kato H, Imbe T, Nemoto H (2008a) QTL analysis of brown spot resistance in rice (Oryza sativa L.). Breed Sci 58(1):93-96

Sato H, Ando I, Takeuchi Y, Hirabayashi H, Arase S, Kihara J, Nemoto H (2008b) Genetic analysis of brown spot resistance in rice using the 39 chromosome segment substitution lines (CSSLs) derived from crossing Koshihikari and Kasalath. Breed Res 10(Spl1):274

Sato H, Matsumoto K, Ota C, Yamakawa T, Kihara J, Mizobuchi R (2015) Confirming a major QTL and finding additional loci responsible for field resistance to brown spot (Bipolaris oryzae) in rice. Breed Sci 65(2):170-175

Savary S, Willocquet L, Elazegui FA, Castilla NP, Teng PS (2000a) Rice pest constraints in tropical Asia: quantification of yield losses due to rice pests in a range of production situations. Plant Dis 84(3):357-369

Savary S, Willocquet L, Elazegui FA, Teng PS, Van Du P, Zhu DF, Tang QY, Huang SW, Lin XQ, Singh HM, Srivastava RK (2000b) Rice pest constraints in tropical Asia: characterization of injury profiles in relation to production situations. Plant Dis 84(3):341-356

Savary S, Nelson A, Sparks AH, Willocquet L, Hodson D, Duveiller E, Mahuku G, Padgham J, Forbes G, Pande S, Sharma M, Garrett KA, Yuen J, Djurle A (2011) International agricultural research tackling the effects of global and climate changes on plant diseases in the developing world. Plant Dis 95(10):1204-1216

Sayler RJ, Cartwright RD, Yang YN (2006) Genetic characterization and real-time PCR detection of Burkholderia glumae, a newly emerging bacterial pathogen of rice in the United States. Plant Dis 90(5):603-610

Schwanck AA, Meneses PR, Farias CRJ, Funck GRD, Maia AHN, Del Ponte EM (2015) Bipolaris oryzae seed borne inoculum and brown spot epidemics in the subtropical lowland rice-growing region of Brazil. Eur J Plant Pathol 142(4):875-885

Shahjahan AKM, Rush MC, Groth D, Clark CA (2000) Panicle blight. Rice J 15:26-29

Shrestha BK, Karki HS, Ham JH (2014) Genome-wide identification of molecular markers for partial resistance of rice to bacterial panicle blight using highthroughput sequencing data. Phytopathology 104(11):108-108

Shukla VD, Chauhan JS, Variar M, Maiti D, Chauhan VS, Tomar JB (1995) Reaction of traditional rainfed rice accessions to brown spot, blast and sheath rot diseases. Indian Phytopath 48:433-435

Sreedharan A, Menon MR (1974) Studies of the isolates of Helminthosporium oryzae. Indian Phytopath 27:131-133

Tabien RE, Li Z, Paterson AH, Marchetti MA, Stansel JW, Pinson SRM (2002) Mapping QTLs for field resistance to the rice blast pathogen and evaluating their individual and combined utility in improved varieties. Theor Appl Genet 105(2-3):313-324

Takai T, Nonoue Y, Yamamoto SI, Yamanouchi U, Matsubara K, Liang ZW, Lin HX, Ono N, Uga Y, Yano M (2007) Development of chromosome segment substitution lines derived from backcross between indica donor rice cultivar 'Nona bokra' and japonica recipient cultivar 'Koshihikari'. Breed Sci 57(3):257-261

Takeda K, Heta H (1989) Establishing the testing method and a search for the resistant varieties to Fusarium head blight in barley. Jpn J Breed 39(2):203-216

Takita T, Imbe T, Nishiyama H, Tsushima S (1988) Resistance to rice bacterial grain rot in indica and upland rice. Kyushu Agric Res 50:28

Trung HM, Van NV, Vien NV, Lam DT, Lien M (1993) Occurrence of rice grain rot disease in Vietnam. Int Rice Res Notes 18:30

Tsushima S (1996) Epidemiology of bacterial grain rot of rice caused by Pseudomonas glumae. JARQ 30:85-89

Tsushima S, Mogi S, Saito H (1986) Effect of temperature on the growth of Pseudomonas glumae and the development of rice bacterial grain rot. Proc Assoc PI Prot Kyushu 32:14-16

Tsushima S, Mogi S, Naito H, Saito H (1989) Existence of Pseudomonas glumae on the rice seeds and development of the simple method for detecting $P$. glumae from the rice seeds. Bull Kyushu Natl Agric Exp Stn 25:261-270
Uematsu T, Yoshimura D, Nishiyama K, Ibaraki T, Fujii H (1976) Occurrence of bacterial seedling rot in nursery flat, caused by grain rot bacterium Pseudomonas glumae. Ann Phytopathol Soc Jpn 42:310-312

Wamishe Y, Jia Y, Rasheed M, Kelsey C, Belmar S, Gebremariam T (2014) Resistance the ultimate solution for bacterial panicle blight disease of rice. Phytopathology 104(11):124-124

Wasano K, Okuda S (1994) Evaluation of resistance of rice cultivars to bacterial grain Rot by the syringe inoculation method. Breed Sci 44(1):1-6

Yamamoto T, Yonemaru J, Yano M (2009) Towards the understanding of complex traits in rice: substantially or superficially? DNA Res 16(3):141-154

Yamamura K, Yokozawa M (2002) Prediction of a geographical shift in the prevalence of rice stripe virus disease transmitted by the small brown planthopper, Laodelphax striatellus (Fallen) (Hemiptera : Delphacidae), under global warming. Appl Entomol Zool 37(1):181-190

Yasumasa J, Kakizaki M, Fukatsu R, Shimada N (1962) Studies on brown spot disease (2). (in Japanese). Bull Yamagata Agric Exp Stn 1:1-229

Yasunaga T, Wada T, Oosata KF, Hamachi Y (2002) Varietal differences in occurrence of bacterial grain rot in rice cultivars with high palatability. Crop Sci Soc Jpn 68:12-14

Yokoyama T, Okuhara K (1987) Relationship between the occurrence of rice bacterial grain rot, and meteorogical conditions and cultivars of rice. (in Japanase). Proc Assoc PI Prot Kyushu 33:4-8

Yonemaru J, Yamamoto T, Fukuoka S, Uga Y, Hori K, Yano M (2010) Q-TARO: QTL annotation rice online database. Rice 3(2-3):194-203

Yoshii H, Matsumoto M (1951) Studies on the resistance to Helminthosporiose of the rice varieties introduced to Japan (1). (in Japanese). Bull Matsuyama Agric College 6:25-60

Zeigler RS, Alvarez E (1989) Grain discoloration of rice caused by Pseudomonas glumae in Latin America. Plant Dis 73:368

Zeng YX, Ji ZJ, Yang CD (2015) The way to a more precise sheath blight resistance QTL in rice. Euphytica 203(1):33-45

Zhou XG (2014) First report of bacterial panicle blight of rice caused by Burkholderia glumae in South Africa. Plant Dis 98(4):566-566

Zhou XG, McClung AM, Way MO, Jo Y, Tabien RE, Wilson LT (2011) Severe outbreak of bacterial panicle blight across Texas Rice Belt in 2010. Phytopathology 101(6):S205

Zou JH, Pan XB, Chen ZX, Xu JY, Lu JF, Zhai WX, Zhu LH (2000) Mapping quantitative trait loci controlling sheath blight resistance in two rice cultivars (Oryza sativa L.). Theor Appl Genet 101(4):569-573

\section{Submit your manuscript to a SpringerOpen ${ }^{\circ}$ journal and benefit from:}

- Convenient online submission

- Rigorous peer review

- Immediate publication on acceptance

- Open access: articles freely available online

- High visibility within the field

- Retaining the copyright to your article

Submit your next manuscript at springeropen.com 